\title{
High Molecular Diversity of the Fungus Guignardia citricarpa and Guignardia mangiferae and New Primers for the Diagnosis of the Citrus Black Spot
}

\author{
Danyelle Stringari ${ }^{1}$, Chirlei Glienke ${ }^{1 *}$, Daniel de Christo ${ }^{1}$, Walter Maccheroni Jr. $^{2}$ and \\ João Lucio de Azevedo ${ }^{2}$ \\ ${ }^{1}$ Departamento de Genética; Universidade Federal do Paraná; C. P.: 19071; 81531-990; Curitiba -PR - Brasil. \\ ${ }^{2}$ Departamento de Genética; Universidade de São Paulo; C. P.: 9; 13418-900; Piracicaba - SP - Brasil
}

\begin{abstract}
RAPD markers were used to investigate the distribution of genetic variability among a group of Guignardia citricarpa, G. mangiferae, and Phyllosticta spinarum isolates obtained from several hosts in Brazil, Argentina, Mexico, Costa Rica, Thailand, Japan, United States and South Africa. Pathogenic isolates G. citricarpa Kiely (anamorph form P. citricarpa McAlp Van Der Aa) are the etiological agent of the Citrus Black Spot (CBS), a disease that affects several citric plants and causes substantial injuries to the appearance of their fruits, thus preventing their export. Several previous studies have demonstrated the existence of an endophytic species with high morphological similarity to the causal agent of CBS that could remain latent in the same hosts. Consequently, the identification of the plants and fruits free from the causal agent of the disease is severely hampered. The RAPD analysis showed a clear discrimination among the pathogenic isolates of $\mathrm{G}$. citricarpa and endophytic isolates (G. mangiferae and P. spinarum). In addition, a Principal Coordinate Analysis (PCO) based on a matrix of genetic similarity estimated by the RAPD markers showed four clusters, irrespective of their host or geographical origin. An Analysis of Molecular Variance (AMOVA) indicated that $62.8 \%$ of the genetic variation was found between the populations (G. citricarpa, G. mangiferae, P. spinarum and Phyllosticta sp.). Substantial variation was found in the populations (37.2\%). Exclusive RAPD markers of isolates of G. citricarpa were cloned, sequenced and used to obtain SCARS (Sequence Characterized Amplified Regions), which allowed the development of new specific primers for the identification of G. citricarpa PCR (Polymerase Chain Reaction) analysis using a pair of primers specific to pathogenic isolates corroborating the groupings obtained by the RAPD markers, underscoring its efficiency in the identification of the causal agent of CBS.
\end{abstract}

Key words: Guignardia, SCARS, Citrus Black Spot, Citrus, Diagnosis, RAPD

\section{INTRODUCTION}

The orange fruit is currently the most cultivated plant in the world, with an annual production exceeding 60 million tones. Brazil is responsible for nearly a third of the world production of orange, as well as $85 \%$ of the control of the international orange juice market. Therefore, the cultivation of citric fruits is among the most important activities in Brazilian agrobusiness (Agrianual, 2005).

However, citriculture has several phytosanitary problems, particularly the Citrus Black Spot (CBS), which has caused substantial losses due to the need for pulverization with fungicides for their

\footnotetext{
*Author for correspondence: cglienke@ufpr.br
} 
control and the ensuing increases in the costs of production (Agrianual, 2005). There is considerable depreciation in the value of fruits with CBS in the in natura market, with strong opposition to its import by the European Union, which is currently Brazil's most important consumer. Therefore, the diagnosis of the fruits destined for export is of fundamental importance. The CBS is caused by the fungus Guignardia citricarpa Kiely (anamorphic form is Phyllosticta citricarpa Van Der Aa) and was first described in 1895 in Australia in orange fruits of the 'Valência' variety, causing considerable losses. This disease is currently found in several countries, with the maximum impact in South Africa, Japan, Argentina, and particularly in Brazil, where the disease has been reported most frequently after 1995 and is strongly affecting the local citriculture (Feichtenberger, 1996).

Although the identification of the causal agent of CBS can be obtained by the conventional techniques such as culturing and microscopy, these procedures require weeks to be completed. This delay is impractical in the in natura business of the fruit. In addition, there have been reports of the existence of an endophytic species ( $G$. mangiferae) that is very similar morphologically with the causal agent of CBS, inhabiting latently the same hosts (Glienke-Blanco et al., 2002, Baayen et al., 2002). Therefore, the identification of the plants and fruits free from the causal agent of CBS is made even more difficult. Although these two fungus species are morphologically nearly identical, their physiological differences are clear. Baayen et al. (2002) showed that the most significant morphological difference among $G$. citricarpa and $G$. mangiferae is the thickness of the mucoid conidial sheath, which is smaller than $1.5 \mu \mathrm{m}$ in the former but ranges between 1.5 and $3.0 \mu \mathrm{m}$ in the latter. However, the long time required for the isolation, culturing and pycnidium formation makes this method unsuitable for the quarantine purposes.

Baayen et al. (2002) investigated ITS sequences and showed that the endophytic species isolated in Citrus spp. was the anamorphic state of $P$. capitalensis. Okane et al. (2001) reported the endophytic occurrence of $P$. capitalensis inhabitanting Ericaceae plants, describing the teleomorphic state as G. endophyllicola. A survey of the taxonomic literature showed that the oldest name associated with the teleomorphic state of these isolates probably was G. mangiferae A. J. Roy, described in 1968. In fact, the endophytic $G$. mangiferae is found inhabiting a wide range of hosts, and probably has been repeatedly described from many different host species, causing extensive several cases of synonymy.

The present work investigated the Brazilian isolates of Guignardia spp. and Phyllosticta spp. with the following objectives: 1) to verify the endophytic occurrence of G. citricarpa and $G$. mangiferae in Citrus spp and llex paraguariensis; 2) to assess the genetic variability and population structure of endophytic isolates, as well as those obtained from CBS lesions; 3) to differentiate the isolates of $G$. mangiferae and G. citricarpa based on RAPD markers and to develop SCARS specific to the causal agent of CBS. The development and validation of an identification method for $G$. citricarpa using PCR could expedite the identification process of contaminated fruits and orchards.

\section{MATERIALS AND METHODS}

\section{Fungal Material}

The isolates investigated in this work were obtained from monosporic cultures. The strains of $G$. citricarpa were isolated directly from CBS injuries. The endophytic strains of $G$. mangiferae and Phyllosticta spp. were isolated from healthy host plants without any apparent lesions (Pimentel et al., 2006). The geographical origin, host plant and nature (endophytic or pathogenic) of all the isolates are listed in Tables 1 and 2.

Three strains of G. citricarpa and three strains of $G$. mangiferae that were tested positive and negative for pathogenicity, respectively (Baldassari, 2005) were used in the validation of the PCR diagnostic (Table1).

\section{DNA Extraction}

The fungi were grown in the complete agar medium (Azevedo and Costa, 1973) at $28^{\circ} \mathrm{C}$ for three days. The mycelium was then harvested, frozen at $-20^{\circ} \mathrm{C}$ and freeze-dried. The dried mycelium was placed in a mortar and ground with liquid nitrogen and a pestle into a fine powder. The genomic DNA was isolated according to the protocol of Raeder and Broda (1985). The DNA was precipitated with ethanol, washed in ethanol (70\%), dried and dissolved in milli-Q sterilized 
water. The DNA solution was treated with RNAse $(50 \mu \mathrm{g} / \mathrm{mL})$ and the concentration of DNA was measured by agarose gel electrophoresis, followed by staining with ethidium bromide.

Table 1 - Isolates of the citrus pathogen G. citricarpa, the citrus endophyte G. mangiferae, and Phyllosticta species from other host species used in the RAPD analyses and PCR tests as reference isolates (Baayen et al., 2002; Baldassari, 2005).

\begin{tabular}{|c|c|c|}
\hline Isolates & Nature / Host & Origin \\
\hline \multicolumn{3}{|l|}{ G. citricarpa (P. citricarpa) } \\
\hline PC3C, PC6C, PC8C, PC9C, PC10C & Pathogen/Citrus sp & South Africa ${ }^{(1)}$ \\
\hline $\mathrm{PC} 12 \mathrm{C}$ & Pathogen/Citrus sp & Brazil $^{(1)}$ \\
\hline $\mathrm{PC} 15 \mathrm{C}$ & Pathogen/Citrus sp & Japan $^{(1)}$ \\
\hline PC18C & Pathogen/Citrus sp & Mexico $^{(1)}$ \\
\hline PC28/05, PC32/05, PC33/05 & Pathogens/Citrus sp ${ }^{\mathrm{P}}$ & Brazil $^{(2)}$ \\
\hline \multicolumn{3}{|l|}{ G. mangiferae (P. capitalensis) } \\
\hline EC1C & Endophyte/Pittosporaceae & $\mathrm{EUA}^{(1)}$ \\
\hline $\mathrm{EC} 2 \mathrm{C}$ & Endophyte/Zamiaceae (cycad palm family) & South Africa ${ }^{(1)}$ \\
\hline $\mathrm{EC} 4 \mathrm{C}$ & Endophyte/Zamiaceae (cycad palm family) & $\mathrm{EUA}^{(1)}$ \\
\hline EC5C & Endophyte/Moraceae (mulberry family) & Thailand ${ }^{(1)}$ \\
\hline $\mathrm{EC} 7 \mathrm{C}, \mathrm{EC} 17 \mathrm{C}$ & Endophytes/Citrus sp & $\mathrm{EUA}^{(1)}$ \\
\hline $\mathrm{EC} 11 \mathrm{C}$ & Endophyte/Sapotaceae & EUA $^{(1)}$ \\
\hline EC13C & Endophyte/Lauraceae & South Africa ${ }^{(1)}$ \\
\hline $\mathrm{EC} 14 \mathrm{C}$ & Endophyte/Araliaceae & South Africa ${ }^{(1)}$ \\
\hline $\mathrm{EC} 16 \mathrm{C}$ & Endophyte/Fortunella margarita & EUA $^{(1)}$ \\
\hline EC19C & Endophyte/Araliaceae (ginseng family) & Costa Rica ${ }^{(1)}$ \\
\hline EC20C & Endophyte/Rubiaceae & EUA $^{(1)}$ \\
\hline $\mathrm{EC} 21 \mathrm{C}$ & Endophyte/Camellia japonica & $\mathrm{EUA}^{(1)}$ \\
\hline $\mathrm{EC} 01 / 05^{\mathrm{N}}, \mathrm{EC} 19 / 05^{\mathrm{N}}, \mathrm{EC} 22 / 05^{\mathrm{N}}$ & Endophytes/Citrus sp & Brazil (2) $^{(2)}$ \\
\hline
\end{tabular}

${ }^{1}$ Strains kindly provided by Dr. George Carroll / University of Oregon-USA.

${ }^{2}$ Dr. Antonio de Goes, UNESP/Jaboticabal - SP/Brazil

${ }^{\mathrm{P}}$ Positive strains in pathogenicity tests for CBS (Baldassari, 2005).

${ }^{\mathrm{N}}$ Negative strains in pathogenicity tests for CBS (Baldassari, 2005).

\section{RAPD}

Random Amplified Polymorphic DNA (RAPD) analysis was carried out using $50 \mathrm{ng}$ of genomic DNA. The amplification reaction was done in a final volume of $25 \mu \mathrm{l}$ containing $1.5 \mathrm{U}$ of Taq DNA polymerase (Invitrogen, Carlsbad, CA, USA), $0.4 \mu \mathrm{M}$ of primer, $0.2 \mathrm{mM}$ of dNTPs (Pharmacia, Freiburg, Germany), $3.0 \mathrm{mM}$ of $\mathrm{MgCl}_{2}$ and $1 \mathrm{X}$ PCR Buffer (50 mM of KCl, 200 $\mathrm{mM}$ of Tris-HCl, $\mathrm{pH}$ 8.4). Negative controls containing all the components, except genomic DNA were included in all the experiments. The primers selected were obtained from Operon Technologies (Alameda, CA, USA): OPX08, OPX12, OPX13, OPX14, OPX17, OPX19.

The amplification was performed in a MJ Research $^{\circledR}$ thermocycler (Watertown, MA, USA) according to the following steps: initial denaturation at $94^{\circ} \mathrm{C}$ for $2 \mathrm{~min}$, followed by 40 cycles of denaturation for $1 \mathrm{~min}$. at $94^{\circ} \mathrm{C} /$ annealing for $1.5 \mathrm{~min}$ at $37^{\circ} \mathrm{C} /$ extension for 2 min. at $72^{\circ} \mathrm{C}$, and a final extension for $3 \mathrm{~min}$ at $72^{\circ} \mathrm{C}$.

\section{Data Analysis}

RAPD markers were interpreted as binary data based on the presence or absence of bands. A matrix of Jaccard genetic similarities (Sneath and Sokal, 1973) was generated using NTSYS 2.1 (Rohlf, 1997). A significance test of the correlation between the genetic similarity matrix and a cophenetic matrix of the dendrogram was carried out with the Mantel matrix correlation test (Mantel, 1967). From the genetic similarity matrix, a Principal Coordinate Analysis (PCO) was performed to verify possible clustering of the isolates. Based on the similarity values, an UPGMA cluster was generated proceeding an artificial dendrogram. The robustness of each node in the dendrogram was evaluated by the bootstrap analysis (Felsenstein, 1985) using the software Bood v.3.03 (Coelho, 2005). An analysis of molecular variance (AMOVA) was conducted using the software Arlequin 3.0 (Excoffier et al., 2005). 
Table 2 - Isolates of the citrus pathogen G. citricarpa, the citrus endophyte G. mangiferae, Phyllosticta spinarum and Phyllosticta species from other host species used in the RAPD analyses and PCR tests.

\begin{tabular}{|c|c|c|}
\hline Isolates & Nature / Host & Origin \\
\hline \multicolumn{3}{|l|}{ G. citricarpa (P. citricarpa) } \\
\hline $\begin{array}{l}\text { PC7LI3, PC7LA2, PC7LD6, PC7LB6, } \\
\text { PC7LB8, PC7LE10 }\end{array}$ & Pathogens/Citrus sp & SP - Brazil ${ }^{(1)}$ \\
\hline PC13/96, PC13, PC19, РCP6 & Pathogens/Citrus sp & SP - Brazil ${ }^{(2)}$ \\
\hline \multicolumn{3}{|l|}{ G. mangiferae (P. capitalensis) } \\
\hline ECOL23, EC145, EC131, EC01/96, EC16/96 & Endophytes/Citrus spp & SP - Brazil ${ }^{(3)}$ \\
\hline $\begin{array}{l}\text { ECMi1, ECMi4, ECMi5, ECMi6, ECMi7, } \\
\text { ECML2, ECML7, }\end{array}$ & Endophytes/Citrus spp & PR - Brazil ${ }^{(4)}$ \\
\hline $\begin{array}{l}\text { EEM09, EEM39, EEM75, EM153, EEM163, } \\
\text { EEM176, EEM192, EEM202, EEM375, EEM371 }\end{array}$ & Endophytes/Ilex paraguariensis & PR - Brazil ${ }^{(5)}$ \\
\hline PGB 1515 & Pathogen/Psidium guajavae & Brazil $^{(6)}$ \\
\hline EG3Z & Endophyte/Paullinia cupana & Manaus - Brazil ${ }^{(7)}$ \\
\hline ECF75LP & Endophyte/Citrus sp & Tucumám - Argentina ${ }^{(8)}$ \\
\hline \multicolumn{3}{|l|}{ Phyllosticta sp } \\
\hline ECPR5, ECPR6, ECPR8 & Endophyte/Citrus limon & PR - Brazil ${ }^{(9)}$ \\
\hline $\begin{array}{l}\text { Dr. Antonio de Goes, UNESP/Jaboticabal - SP/Brazil } \\
\text { Centro de Citricultura Sylvio Moreira - IAC - SP/Brazil } \\
\text { Strains isolated by Blanco (1999). } \\
\text { Strains isolated in the metropolitan region of Curitiba - } \\
\text { Strains isolated by Penna (2000). } \\
\text { Strain kindly provided by Dr. Luimar José Tozetto / UnB } \\
\text { Strain isolated and kindly provided by Dr. J. O. Pereira - } \\
\text { Strain kindly provided by Dr. Estela Duran, Tucumám - } \\
\text { Strains isolated in the region of Rio Negro - PR, by Blan }\end{array}$ & tringari, 2004). & \\
\hline
\end{tabular}

\section{Development of Specific PCR Primers}

Following the detection of RAPD bands that were specific to strains of $G$. citricarpa, a new RAPD reaction was carried out using the DNA from isolate PC13/96 and the OPX14 primer. The DNA from the purified band (p373) was used, together with the OPX14 primer, in a reamplification reaction using the same conditions as before. This $373 \mathrm{bp}$ fragment was purified, cloned in a $E$. coli DH5 $\alpha$ F using the pGEM-T Easy Vector Systems kit (Promega®, Madison, WI, USA), and sequenced using the T7 Sequencing kit (USB, Cleveland, Ohio, USA) and the sequencing method of double-stranded DNA. The resulting sequence was used to design the following primer pair for G. citricarpa: GCP1 5' AAGTGTGAGTGTCGAAGGTGG 3' and GCP2 5' GACGACTCGCTTTTCTACGGC 3', resulting in a 340 bp amplicon (Blanco, 1999). Reaction conditions were: $1 \mathrm{X}$ PCR buffer $(50 \mathrm{mM}$ of $\mathrm{KCl}$, $200 \mathrm{mM}$ of Tris-HCl, $\mathrm{pH}$ 8.4), $1.5 \mathrm{U}$ of Taq DNA polymerase (Invitrogen, Carlsbad, CA, USA), 0.25 $\mu \mathrm{M}$ of each primer, $0.2 \mathrm{mM}$ of each dNTP (Pharmacia, Freiburg, Germany), 25 ng of DNA and $1.5 \mathrm{mM}$ of $\mathrm{MgCl}_{2}$ in a total volume of $25 \mu \mathrm{l}$.
Amplification was carried out in a MJ Research ${ }^{\circledR}$ thermocycler (Watertown, MA, USA) using the following conditions: initial denaturation at $94^{\circ} \mathrm{C}$ for $2 \mathrm{~min} ; 35$ cycles of $1 \mathrm{~min}$ at $94^{\circ} \mathrm{C} / 1 \mathrm{~min}$ at $69^{\circ} \mathrm{C} / 1 \mathrm{~min}$ at $72^{\circ} \mathrm{C}$; and a final extension of 3 min at $72^{\circ} \mathrm{C}$.

A positive control for the amplification was conducted in a reaction with the primers ITS1/ITS4 and the conditions described in White et al. (1990). Reaction conditions were: $50 \mathrm{ng}$ of DNA, 1 X PCR buffer $(50 \mathrm{mM}$ of $\mathrm{KCl}, 200 \mathrm{mM}$ of Tris-HCl, $\mathrm{pH} 8.4$ ), $1.5 \mathrm{U}$ of $\mathrm{Taq}$ polymerase (Invitrogen, Carlsbad, CA, USA), $0.25 \mu \mathrm{M}$ of each primer, $0.2 \mathrm{mM}$ of each dNTP (Pharmacia, Freiburg, Germany), and $1.5 \mathrm{mM}$ of $\mathrm{MgCl}_{2}$ in a total volume of $25 \mu$ l. Amplification was carried out in a MJ Research ${ }^{\circledR}$ thermocycler (Watertown, MA, USA) using the following conditions: initial denaturation at $94^{\circ} \mathrm{C}$ for $2 \mathrm{~min} ; 35$ cycles of $1 \mathrm{~min}$ at $94^{\circ} \mathrm{C} / 1 \mathrm{~min}$ at $50^{\circ} \mathrm{C} / 1 \mathrm{~min}$ at $72^{\circ} \mathrm{C}$; and a final extension of $3 \mathrm{~min}$ at $72^{\circ} \mathrm{C}$.

The robustness and the specificity of the primer pair were assessed using DNA from the reference isolates of G. citricarpa and G. mangiferae (Table 1) that had been validated using the pathogenicity 
tests (Baldassari, 2005). Specificity was also tested against the cultures of the common citrus endophyte, Colletotrichum gloeosporioides, and against leaves of orange and lemon trees.

\section{RESULTS AND DISCUSSION}

RAPD markers were used in the present study to investigate the distribution of genetic variability among the isolates of G. citricarpa, G. mangiferae and Phyllosticta spp. (Tables 1 and 2), resulting in 141 polymorphic markers. Species-specific bands were found both for $G$. citricarpa and $G$. mangiferae.

The analysis using RAPD markers allowed for the discrimination of the isolates into four main groups with 5\% genetic similarity. The high bootstrap values $(P>90 \%$; Fig. 1) confirmed the robustness of the groupings. A Principal Coordinate Analysis
(PCO) based on the genetic similarities estimated with the RAPD markers (Fig. 2) showed high diversity of the isolates of groups I and II, with the clear formation of subgroups that corroborated those observed in Fig. 1.

These four groups (I - IV in Figs. 1 and 2) were considered as distinct populations according to the AMOVA, which indicated that $62.8 \%$ of the genetic variation was between the populations, although substantial variation was found in populations $(37.2 \% P<0.0001)$ (Table 3$)$. The high genetic variability observed in and among the groups was surprising, given that all the studied strains belonged to the genus Guignardia and its anamorph Phyllosticta. Using the same method, several studies have demonstrated that such low levels of similarity were mainly found among the genera, including the phylogenetically distant ones (Motta et al., 2002; Azevedo et al., 2000; Mehta, 2001).

Table 3 - Analysis of molecular variance (AMOVA).

\begin{tabular}{lcccc}
\hline Source of variation & DF & SS & Variation components & \% of variation \\
\hline Among populations & 3 & 599.430 & 18.11 & 62.80 \\
Within populations & 55 & 590.028 & 10.73 & $37.20^{*}$ \\
Total & 58 & 1189.458 & 28.84 & \\
\hline
\end{tabular}

$*(P<0.01)$

The low genetic similarity among these groups has also been observed using data from AFLP and ITS sequences. Baayen et al. (2002) suggested the existence of at least three distinct species of Guignardia coexisting in Brazilian citrus plants: G. citricarpa (causing CBS) and two endophytic species: G. mangiferae (Baayen et al., 2002), and $P$. spinarum.

Group I included the G. citricarpa isolated from the CBS lesions (Fig. 1). The high variability observed in this group did not seem to be associated with the geographical origin of these strains, which were obtained in different continents. Two subgroups could be recognized in this group: Ia and Ib. Subgroup Ia included the strains isolated in Brazil and one strain isolated in South Africa.

Subgroup Ib was composed of strains obtained in Brazil, Japan, South Africa, and Mexico.

Group II included the isolates of considerable genetic diversity, with broad geographical distribution and considerable host diversity (Table $3)$. This was shown by the composition of the subgroup IIa, which included the strains of $G$. mangiferae from South Africa, Brazil, Costa Rica, United States, and Thailand obtained from different hosts (Tables 1 and 2). In addition, the fungus $P$. capitalensis has already been described as causing disease in orchids (Okane et al., 2001). 


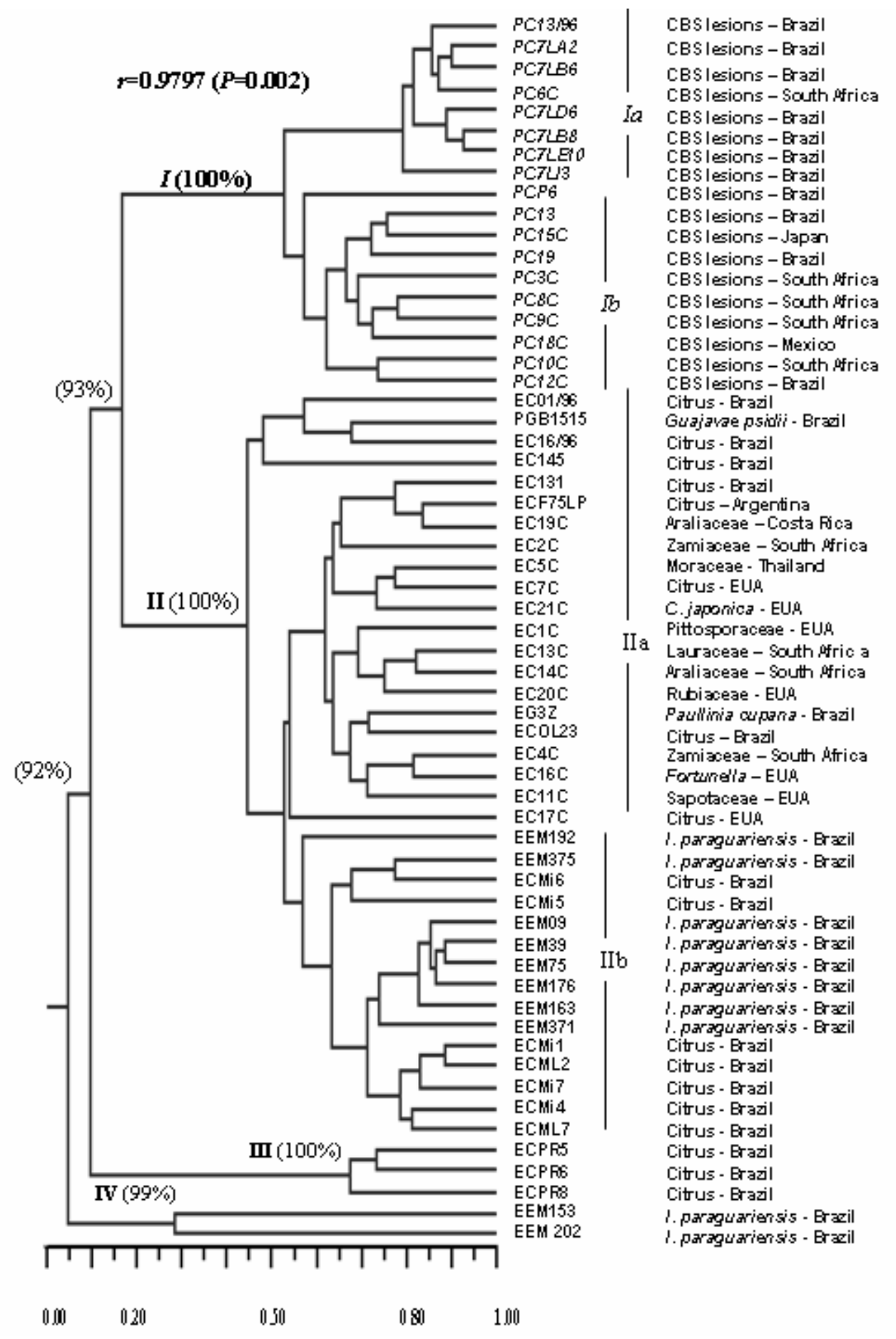

Figure 1 - Dendrogram generated from the genetic similarity matrix obtained using RAPD analysis of the isolates from Tables 1 and 2. Group I: G. citricarpa; Group II: G. mangiferae and Phyllosticta sp.; Group III: Phyllosticta sp, Group IV: Phyllosticta sp. Bootstrap values (\%) of each group are shown in parentheses. 


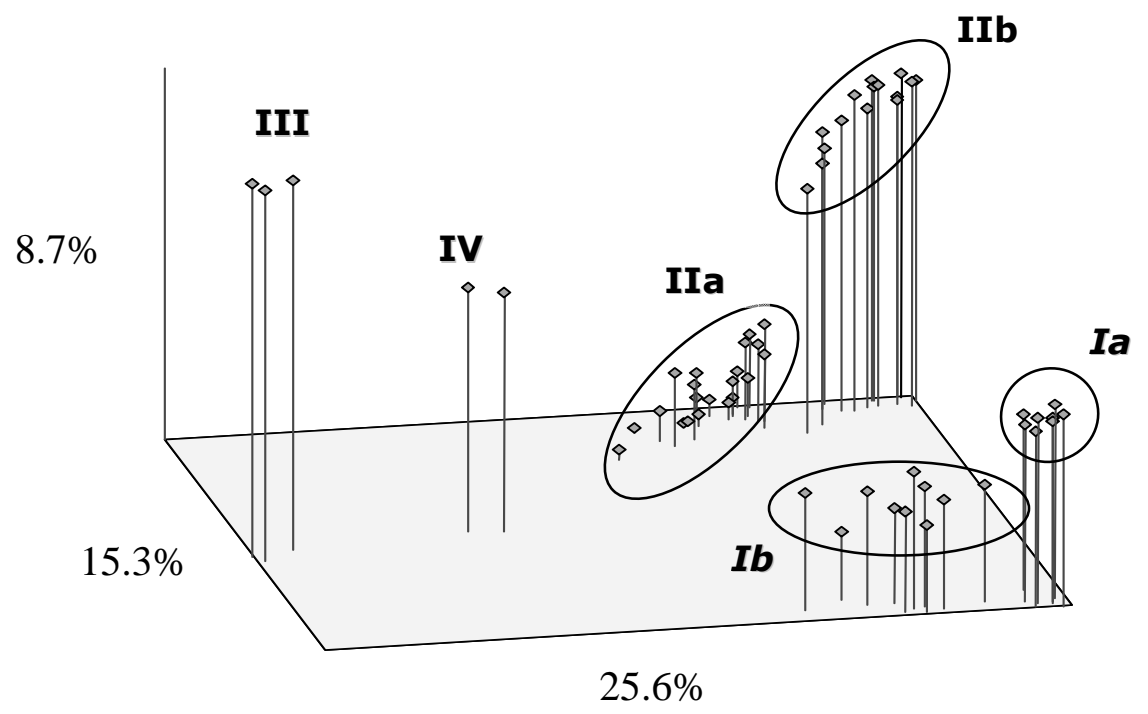

Figure 2 - Principal Coordinate Analysis (PCO) of endophytes based on genetic similarity. Group I: G. citricarpa; Group II: G. mangiferae and Phyllosticta sp.; Group III: Phyllosticta sp., Group IV: Phyllosticta sp. Ia, Ib, IIa e IIb indicate the subgroups identified in Figure 1.

Subgroup IIa included all the reference strains of $G$. mangiferae, six endophytic isolates from citrus, one endophytic isolate from Paullinia cupana (Guaraná), and the strain PGB1515 obtained from a lesion in Guajavae psidii (Table 1). The presence of the Guignardia psidii, a pathogen of the guava tree, in subgroup IIa indicated that this strain might belong to the $G$. mangiferae species and was classified as $G$. psidii due to its host plant in another case of synonymy. This reinforced the idea that the same microorganism could behave as an endophyte or as a pathogen depending on the host. This difficulty in establishing the limits between the endophytic and pathogenic species has been underscored by several authors (e.g. Azevedo J.L. et al., 2000; Araújo, et al., 2000). On the other hand, given the high genetic diversity in group II, it was possible that more than one species of Guignardia similar to $G$. mangiferae was endophytic in these plants.

Eight endophytic isolates obtained from Ilex paraguariensis (erva-mate) in 2000 were classified in subgroup $\mathrm{IIb}$, as well as seven endophytes isolated from citric plant, all of which in the plants located in the State of Paraná, Brazil. It was noteworthy that although they were obtained from distantly related hosts, the strains in this subgroup showed genetic similarity higher than those obtained from the same host plants, such as ECMi5 and ECOL23 (Fig. 1). The formation of the subgroup IIb indicated a tendency for grouping strains based on the geographical location of their host plants.

Despite the genetic diversity observed in group II, all the isolates were considered as belonging to the species $G$. mangiferae ( $P$. capitalensis). Future studies including the sequencing of the ITS1-5.8SITS2 region of the rDNA might help elucidate this issue.

Group III included three isolates of Phyllosticta sp. endophytic of $C$. limon obtained in the municipality of Rio Negro, Paraná, Brazil in 1997. These isolates showed low genetic similarity $(<10 \%)$ with the remaining isolates. These results not only corroborated the data obtained using other markers by Baayen et al. (2002), but also suggested that these strains could belong to another species of Phyllosticta. Sequencing data (not shown) suggested that these strains belonged to $P$. spinarum. The positioning of these lineages in relation to the remaining groups was clearly shown by the PCO in Fig. 2. Group IV was composed only of two endophytic isolates from Ilex paraguariensis (Figs. 1 and 2), which showed low genetic similarity with the remaining groups (Fig. 1). In addition, they were 
intermediate between group III and the remaining isolates of $G$. mangiferae and $G$. citricarpa according to the PCO (Fig. 2). Given that it was not possible to identify the species based on the morphological characters alone, the strain was classified as Phyllosticta sp. Therefore, there were at least three species that are morphologically similar to G. citricarpa and were endophytic in Citrus spp. and Ilex paraguariensis in Brazil, namely G. mangiferae, $P$. spinarum and Phyllosticta sp.

It was clear that the isolation from Citrus spp. that were morphologically similar to $G$. citricarpa did not necessarily meant that the host was contaminated with the causal agent of CBS. The identification using the morphological and physiological characters was imprecise and time-consuming, being inadequate for the analysis of fruits to export (Baayen et al., 2002). Thus, it was necessary to develop diagnostic methods that would be rapid and efficient (Bonants et al., 2003).
Results also underscore the efficiency of RAPD markers, not only in the studies of population structure and in the assessment of genetic variability in fungus populations, but also to suggest the presence of distinct species of a given genus in the surveys of the endophytic community of the studied hosts.

\section{Development of Specific PCR Primers}

The strains in Tables 1 and 2 were tested using PCRs with the GCP1/GCP2 primer pair. Only strains in Group I (Fig. 1) showed the amplification of a band of approximately $350 \mathrm{bp}$ (Fig. 3).

The primers ITS1 and ITS4 were used as positive controls of the amplification (White et al., 1990). These primers are universal for fungi and allow for the amplification of the ITS1 $-5.8 \mathrm{~S}$ - ITS2 region of the rDNA. All the strains amplified an approximately $650 \mathrm{bp}$ fragment (Fig. 3), which was consistent with the expected fragment sizes ca. 700 bp for ascomycete (White et al., 1990).

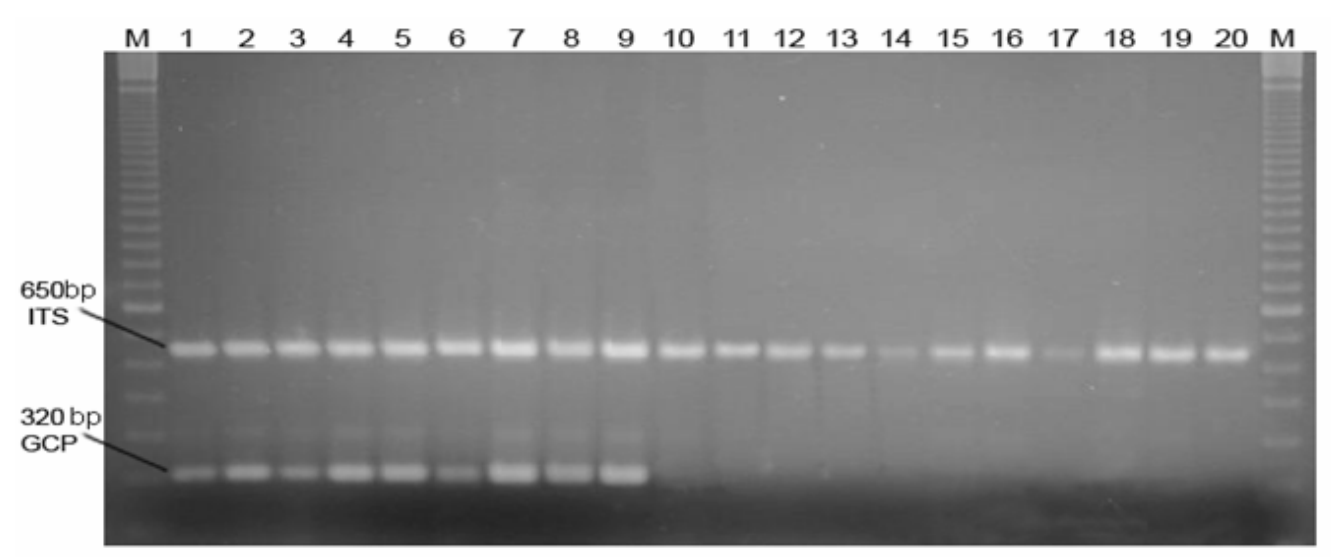

Figure 3 - Agarose gel electrophoresis of PCR using the primer pairs GCP1/GCP2 and ITS1/ITS4, and isolates of G. citricarpa and G. mangiferae. Legend: M: 100 bp. DNA Ladder. 1: Reference strain of G. citricarpa PC28/05 (Table 1); 2 - 9: G. citricarpa (Table 2); 10: Reference strain of G. mangiferae EC22/05 (Table 1); 11 - 20: G. mangiferae (Table 2).

Therefore, the isolates of the pathogenic fungus G. citricarpa obtained from several different countries could be discriminated from the endophytic strains of Guignardia spp. isolated from Citrus spp. using the GCP1 and GCP2 primers. The correct assignment of the strains of
G. citricarpa and G. mangiferae (Fig. 4) validated in the pathogenicity test for CBS (Baldassari, 2005) demonstrated the efficiency in obtaining the SCARS and developing new primers for the identification of the causal agent of CBS. 


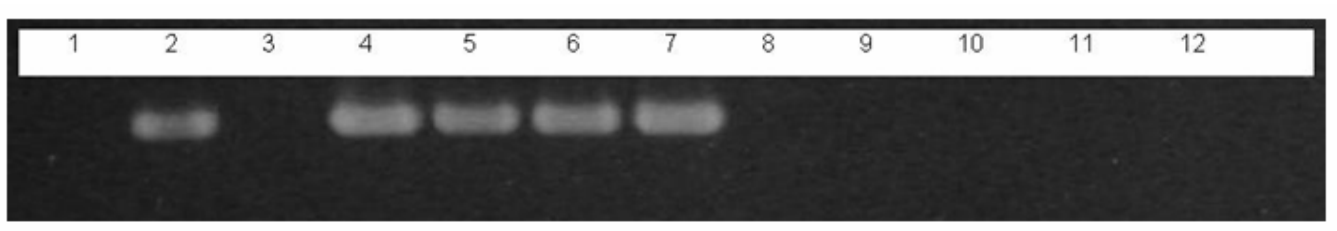

Figure 4 - Agarose gel electrophoresis of PCR using the primer pair GCP1/GCP2 and isolates of G. citricarpa, G. mangiferae and Phyllosticta sp. 1: Negative control without DNA; 2: pGEM-T: plasmid containing the 373bp cloned fragment; 3: P. spinarum (ECPR05); 4 - 6: Reference strains of G. citricarpa (PC28/05, PC32/05, PC33/05); 7: Strain PC13/96 of G. citricarpa; 8 - 10: Reference strains of G. mangiferae (EC 01/05, EC19/05, EC22/05); 11: Negative control: Colletotrichum gloeosporioides; 12: Negative control: DNA of citrus leaves.

\section{CONCLUSIONS}

The high genetic variability observed among the groups obtained using RAPD markers corroborated previous studies (Baayen et al., 2002; Rodrigues et al., 2004) with respect to the existence of at least three distinct species of Guignardia and its anamorph Phyllosticta that were very similar morphologically to the pathogen G. citricarpa, coexisting in Citrus spp. and hampering the identification of the plants and fruits free from the causal agent of CBS.

The use of RAPD markers allowed for the classification of isolates into G. citricarpa, $G$. mangiferae and Phyllosticta sp.. The fact that most endophytic isolates from different hosts and regions could be grouped as belonging to $G$. mangiferae confirmed that a single fungus species could endophytically colonize several host species. In addition, the high genetic similarity between the strain of G. psidii, a guava pathogen, with the strains of $G$. mangiferae indicated that the same microorganism might be found acting as an endophyte in some plants and as a pathogen in others. In other words, G. mangiferae could colonize certain types of the plants without causing symptoms of CBS (citric plants and other hosts) and became pathogenic in other plant species (guava trees and orchids).

The GPC1/GCP2 was efficient in the identification of G. citricarpa as the causal agent of CBS through PCR.

\section{ACKNOWLEDGEMENTS}

We thank Dr. Carlos Aguilar-Vildoso (Instituto Agronômico de Campinas/Brazil) and Dr. Antonio de Goes (UNESP/Jaboticabal, SP - Brazil) for providing some of the fungal strains, and the Brazilian agencies $\mathrm{CNPq}$ and FAPESP for financial support.

\section{RESUMO}

Marcadores de RAPD foram utilizados para investigar a distribuição da variabilidade genética de linhagens de Guignardia citricarpa, G. mangiferae, e Phyllosticta spinarum isolados em diversos hospedeiros no Brasil, Argentina, México, Costa Rica, Tailândia, Japão, EUA e África do Sul. O fungo Guignardia citricarpa Kiely (Phyllosticta citricarpa McAlp Van Der Aa) é o agente causal da Mancha Preta dos Citros (CBS), uma doença que afeta diversas plantas cítricas, causando dano a aparência dos frutos, prejudicando a exportação. Diversos estudos têm demonstrado a existência de uma espécie endofítica muito semelhante morfologicamente a G. citricarpa, e que permanece de forma endofítica no mesmo hospedeiro. Dificultando assim, a identificação de plantas e frutos livres do agente causa da CBS. A análise do perfil de RAPD revelou uma clara discriminação entre isolados patogênicos de G. citricarpa e isolados endofíticos (G. mangiferae e P. spinarum). A Análise de Coordenadas Principais (PCO) baseada na matriz de similaridade genética dos marcadores RAPD, demonstrou a formação de quatro grupos, sem relação com origem geográfica ou com hospedeiros utilizados. A análise de Variância de Marcadores Moleculares (AMOVA) indicou que $62,8 \%$ da variação genética é encontrada entre as populações (G. citricarpa, G. mangiferae, P. spinarum and Phyllosticta sp.). Entretanto, 
variação substancial foi encontrada dentro destas populações $(37,2 \%)$. Bandas de RAPD exclusivas de isolados de G. citricarpa foram clonadas, sequenciadas e utilizadas na obtenção de SCARS (Sequence Characterized Amplified Regions), que permitiram o desenvolvimento de novos primers específicos para a identificação de G. citricarpa. Reações de PCR (Polymerase Chain Reaction) utilizando este par de primers corroboraram os agrupamentos obtidos pelos marcadores de RAPD, revelando sua eficiência na identificação do agente causal da CBS.

\section{REFERENCES}

Agrianual 2005: Anuário da Agricultura Brasileira. São Paulo: FNP 2005, p.785.

Araújo, J., Silva, A.C., Azevedo, J.L. (2000), Isolation of endophytic actinomycetes from roots and leaves of maize (Zea mays L.). Braz. Arch. Biol. Technol, 43 (4), 447-451.

Azevedo, J.L. and Costa, S. O. P. (1973), Exercícios práticos de genética. São Paulo: Nacional / EDUSP. 288p.

Azevedo, J.L., Maccheroni Jr., W., Pereira, J.O., Araújo, W.L. (2000), Endophytic microorganisms: a review on insect control and recent advances on tropical plants. Electr. J. Biotecnol., 3, 40-65.

Azevedo, A.C.S., Furlaneto, M.C., Sosa-Gómez, D.R., Fungaro, M.H.P. (2000), Molecular characterization of Paecilomyces fumoroseus (Deuteromycotina: Hyphomycetes) isolates. Scientia Agrícola, 57, 729732.

Baayen, R.P., Bonants, P.J.M., Verkley, G., Carroll, G.C., van der Aa, H.A., de Weerdt, M., van Brouwershaven, I.R., Schutte, G.C., Maccheroni, W., Glienke-Blanco, C., Azevedo, J.L. (2002), Nonpathogenic isolates of the citrus black spot fungus, Guignardia citricarpa, identified as a cosmopolitan endophyte of woody plants, Guignardia mangiferae (Phyllosticta capitalensis). Phytopathol., 92, 464-477.

Baldassari, R.B. (2005), Patogenicidade, morfologia de colônias e diversidade de isolados de Guignardia citricarpa e G. mangiferae obtidos de Citrus spp. $\mathrm{PhD}$ Thesis, Faculdade de Ciências Agrárias e Veterinárias, Universidade Estadual Paulista, Jaboticabal, São Paulo, Brasil.

Blanco, C.G. (1999), Guignardia citricarpa Kiely: Análise genética, cariotípica e interação com o hospedeiro. PhD Thesis, Piracicaba, Escola Superior de Agricultura Luiz de Queiroz, Universidade de São Paulo, São Paulo, Brasil.
Bonants, P.J.M., Carroll, G.C., Weerdt, M., van Brouwershaven, I.R., Baayen, R.P. (2003), Development and validation of a fast PCR-based detection method for pathogenic isolates of the citrus black spot fungus, Guignardia citricarpa. European J. Plant Pathol., 109, 503-513.

Coelho, A.S.G. (2005), Avaliação de dendrogramas baseados em estimativas de distâncias/similaridades genéticas através do procedimento de bootstrap. Software, V. 3.03. Universidade Federal de Goiás, Goiânia, Brasil.

Excoffier, L., Laval, G., Schneider, S. (2005), Arlequin ver. 3.0: An integrated software package for population genetics data analysis. Evolutionary Bioinformatics Online, 1, 47-50.

Feichtenberger, E. (1996), Mancha preta dos citros no Estado de São Paulo. Laranja, 17, 93-108.

Felsenstein, J. (1985). Confidence limits on phylogenies: an approach using the bootstrap. Evolution, 39, p. 366-369.

Glienke-Blanco, C., Aguilar-Vildoso, C.I., Vieira, M.L.C., Barroso, P.A.V., Azevedo, J.L. (2002), Genetic variability in the endophytic fungus Guignardia citricarpa isolated from citrus plants. Genet. Molec. Biology, 25, 251-255.

Mantel N.A. (1967), The detection of disease clustering and a generalized regression approach. Cancer Res., 27, 209-220.

Mehta, Y.R. (2001), Genetic diversity among isolates of Stemphylium solani from Cotton. Fitopatol. Brasileira, 23, 703-709.

Motta, T.R., Moreira-Filho, C.A., Mendes, R.P., Souza., L.R., Sugizak, M.F., Baueb, S., Calich, V.L.G., Vaz, C.A.C. (2002), Evaluation of DNA polymorphisms amplified by arbitrary primers (RAPD) as genetically associated elements to differentiate virulent and non-virulent Paracoccidioides brasiliensis isolates. FEMS Immun. Medical Microb., 33, 151-235.

Okane, I., Nakagiri, A., Ito, T. (2001), Identity of Guignardia sp. inhabiting ericaceous plants. Can. J. Bot., 79, 101-109.

Penna, E.B., Azevedo, J.L., Glienke, C., Fernandes, J.S.C. (2000), Variabilidade Genética do endofítico Phyllosticta sp isolado de 5 populações de erva-mate (Ilex paraguariensis st. Hill).. In: V Encontro Paranaense de Genética, Maringá, PR, Ed. Universidade Estadual de Maringá, 5, 41.

Pimentel, I.C., Glienke-Blanco, C., Gabardo, J., Stuart, R.M., Azevedo, J.L. (2006), Identification and colonization of endophytic fungi from soybean (Glycine $\max$ (L.) Merril) under different environmental conditions. Braz. Arch. Biol. Technol., 49, 705-711. 
Raeder, U. and Broda, P. (1985), Rapid preparation of DNA from filamentous fungi. Lett. Appl. Microb., 1, 17-20.

Rodrigues, K.F., Sieber, T.N., Grünig, C.R., Holdenrieder, O. (2004), Characterization of Guignardia mangiferae isolated from tropical plants based on morphology, ISSR-PCR amplifications and ITS1-5.8S-ITS2 sequences. Mycol. Res., 108, 45-52.

Rohlf, F.J. (2000), NTSYS-PC Numerical taxonomy and multivariate analysis system. Exeter Software, New York.

Sneath, P.H. and Sokal, R.R. (1973), Numerical taxonomy. Freeman, San Francisco, 573p.
Stringari, D. (2004), Estudo da Variabilidade Genética de Guignardia spp por Meio de Marcadores de RAPD e Sequências ITS. Ms Sc Thesis, Universidade Federal do Paraná, Curitiba, Paraná, Brasil.

White, T.M., Bruns, T., Lee, S., Taylor, J. (1990), Amplification and direct sequencing of fungal ribosomal RNA for phylogenetics. In: Innis, M.A., Gelfand, D.H., Sninsky, J.J., White, T.J. (Eds.). PCR protocols: a guide to methods and applications, $\mathrm{pp}$. 315-321.

Received: February 16, 2007; Revised: August 27, 2007; Accepted: June 25, 2008. 